\title{
Phenomenon: a Conservatory in a Country Town
}

\author{
Alexander Yakoupov \\ Russian State Specialized Academy of Arts \\ Moscow, Russia \\ E-mail: rgsai@mail.ru
}

\begin{abstract}
The educational level of music teachers largely determines the interest of the population in the music art in general. It is noticed that if the music is taught by highly educated musicians who are able to perform stage concerts in public, they are interesting for pupils as a rule. As the result of their activity is the desire of students to be like their teachers. Where are such musicians being taught?
\end{abstract}

Keywords-secondary musical education; higher musical education; information centre; reviewing; high schoolscomplexes

The point of talking here is not in predicting future but instead in creating it.

Denis de Rougemont

\section{INTRODUCTION. ON IMPORTANCE OF A HIGHER EDUCATION}

The establishment of the higher musical educational institution in Magnitogorsk (the small Russian industrial town in area of Ural not having a status of a regional center) has got quite preachy history. An opening of a state institute by a traditional way required an application of region's government to metropolitan authorities; — only after issuing of a Government decree, its opening was possible. However, this idea found a support in authority structures of neither the town nor the region.

In 90-ies, the shifts in the country allowed starting a real reforming of the musical education. Let me attract managers' attention to the sequence of our operations. Firstly: we initiated a trip-based convocation in Magnitogorsk of conference of directors boards of music high schools of Russia (we needed public and professional support). Secondly: on an open session of our music high school teachers' council together with the directors' board, there was discussed the topic "On development prospects of secondary special musical education". As it was traditional, speakers-heads of the music high schools made reports about students' high performance, creative achievements, victories on contests, etc. Everyone wanted to represent his own educational institution in the best way. It seemed, nobody thought seriously about any prospects conceptualization.

A patchy response was caused my report, in which there was spoken out the seditious in the sense of those days thought that the secondary special education in Russia as a social institution of pedagogical orientation has accomplished tasks set for it and now in actual fact, it became outdated. While outlining my position, I clarified that the idea authors (A.V. Lunacharsky and B.L. Yavorsky) - at establishment (in late 20-ies) of musical training colleges - were conscious of an impossibility of opening 100 to 150 higher educational institutions in the country in short terms. Along with it, a musical culture building-up in the country dictated a necessity of upbringing of well-educated musicians- practicians and especially teachers. The mission was entrusted to music high schools that have accomplished it already to a certain extent. For the time past since then, with secondary musical educational institutions, the entire territory of our country was covered. By them, the thick network of musical schools (about 6 thousands) acting based on financial support of the state budget was provided with personnel. By beginning of 80-ies, the growth of music schools number slowed down; however music high schools kept augmenting their contingents, which resulted in occurrence of sings of overproduction of musicians with the secondary special education. The reality pressed for preparation of specialists of a higher level. Besides, the secondary education in the area of pedagogical activities smelled fishy for parents, whose children had desire to devote themselves to music.

In the end of my report, there was accentuated the point that in view of the commenced in the country democratic transformations, in general, the Russian musical education should be seriously changed. Hence, already now, it was necessary to think about further development of the special musical education. My proposals resolved themselves into a point that as a concrete step, there should be introduced a model of institute-complex on the basis of music high schools and thus it would open a possibility to prepare specialists-musicians with secondary and higher education, which in future would allow softly, without revolutions, to move to training of specialists with higher education. By that time, in Russian regions at every major music high school, there already had functioned music schools; thus for realization of the education complex three-component model, only the highest link was required to be overbuilt.

The discussion of my report proceeded extremely loudly. A lot of questions were asked, in particular about ways of material base improvement, re-training of pedagogical personnel and bringing teachers up to the necessary level of higher educational institutions. I encountered with a necessity of explanations that no way did our concept mean firing of ones and their changing with others specialists (all the more so that finding real higher education institution 
specialists, especially professors and docents, was impossible anywhere - ). According to our estimations, a potential of a number of secondary special educational institutions was so high that after passing a re-training in postgraduate studies or in executive assistantship-probation or defending theses, many teachers could acquire the higher education institution status. There was put forward the proposal to analyze states of leading educational institutions of secondary level from this point of view.

Nevertheless, due to the high variety of opinions, the Directors' Board members refused to render me a support in a rather rigorous form; they refused to make any decisions pushing onto the path of reformism, too. However, they agreed not to hinder the movement of Magnitogorsk's music high school in the proposed direction. After the conference, in a confidential conversation, the chief of department of educational institutions of Culture Ministry of Russia promised rendering his all-round support to the said ideas.

\section{TO THE QUESTION OF TACTICS OF CREATING A HIGHER EDUCATIONAL ESTABLISHMENT}

Gaining no support from educational institutions heads, we developed a tactics of phase-by-phase reforming of our music high school. A first step in this direction was supposed to be an establishment of an educational institution with a status of incomplete higher education (there were reasons to expect a counteraction from part of conservatories and art institutes). Soon in our initiative, a special seminar was conducted, which collected active and efficient persons interested in a progressive development of the Russian musical education. In follow-up of the discussions, there was defined the educational institution concept, which was reflected in a published in the same year collection of scientific-methodic articles ${ }^{*}$.

The conception was formed as a quite detailed document unfolded the main ideas of future transformations. In particular, there was said that what was established was not a higher educational institution but instead a kind of a higher music high school with a status of a college ${ }^{* *}$ providing students with an incomplete higher education.

In the tactics "half-institute", there was contained also an economical component. We becalmed our founders that for those transformations, no additional ruble would be needed - we shall do everything in frame of the previously approved budget estimate.

\section{LORD HelPS ThOSE WHO HELP THEMSELVES}

Having undertaken a trip to Moscow to Culture Ministry of Russia with a prepared decree project, I came to deputyMinister V.V. Kochetkov, who was a legendary person and worked for 35 years in this position, which was a kind of

*Higher musical college. News of professional art education // Compiler-editor A.N. Yakupov, M.M. Berlyanchik. - Magnitogorsk Novosibirsk, 1992.

** In the first version of the RF Law in force "On education", there were designated not three but four levels of higher educational institutions: academy, university, institute and college.
Guinness's record in the world practice. Kochetkov, a philosopher in his education and most experienced manager in the area of culture, realized, too: much of what was done earlier needed a revising, required new approaches. In his eyes, wisdom and fatigue were read, a desire of ridding of the enchained routine. In the course of this meeting, it became clear that despite of his readiness to transformations, not less he was sick and tired of projects not having been backed up with calculations and necessary documents. Also a technological complicity of transformations in Russian reality was understood by him better than by me.

And yet, I succeeded in fumbling strings awakened his interest to the idea of the higher musical college as an initial stair of institute. As a trump card, evidently, the statement served that only he with his experience was able to realize a drama of secondary special educational art institutions continuing preparation of teachers with the secondary education, while in many other spheres of life already specialists with a higher education prevailed. Besides, the signed by him decree on transformation of Magnitogorsk's music high school into a college could represent him as a reformer.

Although, in the course of the meeting, Kochetkov dropped a hint of doubt with the following observation. "Well, how can it be? The Magnitogorsk's music high school will be the higher one, while two Moscow's music high schools will remain secondary?" I replied, "I am not greedy; I have no objections that into the decree there would be entered also two Moscow's music high schools. In such a case, the work in the direction of changes in the Russian musical education will be even more productive". Immediately, the directors of these music high schools were called up, who, as it seemed to me, were given a warning by V.V. Kochetkov preliminary and it was evident that they waited for their invitation to the Ministry. After their arrival, Kochetkov said something like this, "See, the Magnitogorsk's resident came. Asks for my signing a decree on transformation of his educational institution into a higher music school". Both directors asked no questions and even did not ask, what it meant "higher music school".

"So, what shall we do?" Kochetkov asked. "I replied to him that there are secondary educational institutions, not less well-deserved. And he has no objections that you also would be included in this decree. What is your opinion to this?"

"We also have no objections to be higher music schools".

“Then let's alter the decree." Kochetkov summarized.

Three of us - director of Gnesinsky music high school, director of music high school named after Hippolitov-Ivanov and me - brought the renewed decree version for signing. Kochetkov called up his lawyer. This one looked it through, put his visa and the deputy-Minister of culture signed the decree in the presence of three of us.

After driving apart, each of us embarked on his work. However, regularly, the Moscow's colleagues asked us for consultations, as it was evident that on a grade of readiness to the new status, we kept ahead for 2 or 3 years as compared to them. After a lapse of a number of years, the status of 
Gnessinsky music high school after its transformation into the college has never changed yet; - it did not become a higher educational institution. Although, there was an excuse for it: close to it, there was situated the Institute named after Gnessins. In its turn, the director of the music high school named after Hippolitov-Ivanov turned out to be a more active person: Having caught up the idea of an institute establishment, successfully he captivated his personnel with it and conducted reforms. Finally, it resulted at the establishment of the State musical-pedagogical institute named after M.M. Hippolitov-Ivanov.

\section{KNOW THE PROBLEMS OF THE STUFF}

Meanwhile, in connection with the appearance of the higher music school-college in Magnitogorsk, a head of Chelyabinsk's regional board of culture found himself in a rather complicated situation. As soon as he started assisting to Magnitogorsk, immediately, a negative reaction emerged among jealous Chelyabinsk's musicians (Why? Chelyabinsk was a regional center, while Magnitogorsk was not!). Because of this, in presence of people, he had to show some reticence in relation of our innovations. However, everything changed, when we used to remain in his office alone. Such was a tradition: the regional manager was obliged to render high-priority assistance to organizations of the regional center.

Let me make more detailed talk about establishment of higher educational institution structures in the higher music school. There was established the scientific-informational center and several specialized laboratories affiliated to it one of sociological researches, one of scientific-methodic information and one of concert department. We drew out of introduction of new salary rates, in particular, the salary rate of pro-rector of the higher music school on scientific work. Interesting was the situation: the head was director, while his deputy was pro-rector. Along with it, inalterably pacifically, the following formula acted, "The reforms will not require additional financial expenses".

One of the first measures in the course of transfer into the status of the higher music school (college) became the development of alternative curriculums of secondary special education of advanced level on all the subjects of curriculum. All the departments of the higher music school were engaged; an articulate system was introduced of preliminary discussion, internal critical reviewing and programs formation. The external critical reviewing was performed by Novosibirsk's conservatory, chairs of which showed a very attentive and responsible attitude to this task performance.

Invariably, I promoted the idea of such innovations pointing out inexpedience of network development of secondary educational institutions; - much more effective would be their transformation into higher educational institutions-complexes: expenses are the same, meanwhile specialists' preparation quality is quite other. It is possible to decrease secondary level students' contingent and - with aid of the released finance - establish top addition in the form of higher educational institutions. "Halve the contingent and with the same expenses, not only a secondary special educational institution will be preserved but also a higher educational institution will be born". - This formula worked magically upon clerks. I am convinced even now: practically for the same financial means, it is possible to maintain both the higher educational institutions and the middle link. In the middle link, the state does not need to have 500 students - 200 or 250 are enough — and just as much in a higher educational institution. Expenses are almost the same and along with it, what a perspective! And if - in addition - to give to unemployment due consideration among graduates of secondary musical educational institution, this will allow eliminating the social problem, too.

Such problems resolution is possible only on condition of presence of quite strong pedagogical personnel. I am grateful to the personnel of Magnitogorsk's music high school. Honorably, it bore the heaviest burden of the large transformations. It allowed me passing through a real school of work with people. I say it not for beautiful words Indeed, I learned much from the personnel: I learned how to be competent in our business, to read much and to listen music much for overtaking of the stuff, which was missed by me in the past because of a young age foolery; for example to read periodicals, to think by scientific categories, to give a serious approach to documents, to which I started schooling myself achieving scrupulousness in my work. Earlier it seemed a worthless occupation to me - all my aspirations were focused on the concert work. It turned out, polishing of own thoughts was a labor-intensive business. Invariably, an addition to all this was the creative burning, which was inherent to our personnel.

I announced about the newly opened opportunity of obtaining education - on expense of the music high schoolin postgraduate courses and assistantship-training on probation, to prepare and defend theses. Many teachers came forward. To those, who took their chance of the serious re-training, both salary and regular bonuses were preserved. Besides, they could make business-trips for a work in libraries of major towns and visits to higher educational institutions of Moscow and Petersburg. To young scientists, assistance was rendered by specially established for them typing office, which on a free basis performed computer typing of their materials, prepared their works for publication. Also a printing and publication department was established. Personnel appreciated these activities quite positively.

To the sphere of our reforms, a lot of major figures were involved. In particular, twice, I had an occasion of meeting the Russian President B.N. Yeltsin. I will tell about one of these meetings. In 1992, probably, in a mistake, I was invited to the town Tula to All-Russian congress of rectors - after all, de jure, we remained a secondary special educational institution. It is possible that organizers were puzzled with the title of our educational institution - Higher music school. More than 700 heads of higher educational institutions were present.

Prior to the meeting beginning, Chairman of Russian Rectors' Council asked not raising private questions on the plenary meeting and being restricted only by common problems of higher educational institutions. I was 
disappointed because as early as at home I prepared a number of documents addressed to B.N. Yeltsin, planned giving a speech and drawing him into our reforms. Hence, I needed to bypass somehow this requirement.

Let me note that then the higher education in the country experienced not its best time: a salary was systematically delayed; with every year, financing was cut more and more. The mood in the hall was odious. In his speech, B.N. Yeltsin promised much; in confirmation of his words, he read loudly the Decree on transfer of earth to institutes for unlimited uncompensated use and the Decree on rectors' support saying about their right - at retirement - on receiving additionally $75 \%$ of salary upon condition of a job seniority 10 years and more, which, of course, was a serious action.

But even this did not change the mood of the rectors' audience. I sat not far from the presidium; so when discussions commenced, I was one of the first, whom the rostrum was given to. After passing "hi" to Yeltsin from his fellow-countrymen (after all, he was from Ural), I said, "Magnitogorsk is an excellent town; however we've got a lot of problems, in particular, in education. I know, prior to this meeting beginning, Rectors' Council proposed not raising private questions. In order not to violate the collegial agreement, I shall not make them public and just will pass the documents, in which our requests are given on questions of education reforming in Magnitogorsk. I appeal for your support". In the said words, there were not contained any reproaches and problems required immediate their resolution. Unlike me, the rest speakers insisted "Everything is awful. We require changing the financing system", etc.

Yeltsin went toward me in spontaneous manner, as it seemed to me, and took the file. Suddenly, an officer from his personal security squad dashed to him and tore out it from the President's hands but being scared to open it, he rushed about on the stage. Then after giving a consideration to the situation, he asked a stenographer-woman to open it after retreating a safe distance away. The stenographer opened the file and showed to everyone that there was nothing in it except from papers. The audience in the hall laughed, while the beyond measure watchful security officer turned red and huddled himself up in a corner. Yeltsin laughed more than others and after taking the file, he said to me, "I promise that to all applications, you will receive answers and corresponding decisions will be made by me".

Those were key words. As one would expect, of course he did nothing; and more to it, I had never received a reply from him; - everything was drowned in the sea of AllRussian reforms - Notwithstanding, in a break time, the deputy-Minister of culture Vadim Petrovich Demin approached to me and started questioning closely about Magnitogorsk's affairs and then he proposed to me to use the same train for the trip to Moscow, in order that I had a chance to explain everything in detail by the way.

I told him much about the past and the present of our Magnitogorsk's college, a role of music in the town's culture, our great educational work, rich traditions. Also I told that we had a serious intention to increase the level of personnel preparation of Russian musical culture. But for this, it was necessary to develop a network of musical higher educational institutions that would train specialists on a higher level than a music high school can do. If this would come true in Magnitogorsk, there would be quite real establishment of good choirs, orchestras, a philharmonic hall, opening of an opera house. Of course, those were just dreams; however in them an actions program was contained. In the end of the conversation V.P. Demin said to me, "You can rely on me in your innovations, I'll help you". And indeed, he kept his promise and actively rendered us his assistance for all the subsequent years.

\section{ON THE BENEFITS OF BUILDING RELATIONSHIPS WITH REGIONAL LEADERS}

Let us return to the story of the musical institute establishment in Magnitogorsk.

Our college teachers worked hard eager to increase their qualification. This became the main advantage for the idea promotion of the transformation of our higher music school into a higher educational institution of full value. After the idea approval, the work started on preparation of documents necessary for higher educational institution status receiving. It was year 1993; in those days, Yeltsin's slogans were still popular like "Take as much sovereignty as you are able to take" and "Everything is allowed, what is not forbidden"; these sayings played a decisive role in the question of Magnitogorsk's institute establishment. As it was said before, in legislative way, the Law "On education" being in force in those days provided regional authorities with a right of establishment of higher educational institutions.

In order that the musical institute opening in Magnitogorsk would not irritate musicians of our regional center and of conservatories of the country, humbly, we raised concern on establishing of musical-pedagogical institute. Besides with the purpose of encouragement of regional government's commitment, it got necessary to secure ourselves with a letter of the deputy-Minister of culture to the governor of Chelyabinsk's region in support of the Magnitogorsk's initiatives. After its obtaining, there was issued the Decree of region's governor "On transformation of Magnitogorsk's higher music school into Magnitogorsk's state musical-pedagogical institute" with financing from the regional budget. Always, the Magnitogorsk's music high school remained in regional competence sphere. By the way, this principle had been preserved till now, which, definitely, is correct as the region has got a lot of possibilities to maintain its educational institutions decently and besides, it keeps better informed on needs in specialists in its region.

An important step in the process of the musicalpedagogical institute establishment in Magnitogorsk became development of its Founding Charter, which had to define all main aspects of activities of the educational institution of the new type. By its articles, three grades of musical education were joined - primary, middle and higher.

On the first steps of Magnitogorsk's musical institute formation, a great support was rendered by Moscow's conservatory represented by leading professors E.B. Dolinskaya, M.A. Smirnov, M.E. Tarakanov, E.G. Sorokina, 
T.A. Guaidamovich, Yu.N. Рагc as well as other well-known musicians and teachers.

The story of transformation of the mus-ped-institute into a conservatory ${ }^{*}$ is even more notable. The status of the musical institute with pedagogical bias had not satisfied us already. Everyone wanted to have a higher educational institution on preparation of musicians-performers. It was evident: its changing is just a bureaucratic procedure required only correcting of Founding Charter based in corresponding decision of a founder. We made an attempt of the title change for "conservatory" but encountered a resistance from part of the regional government. The head of regional Culture board put it straight. "If I would support you, I would not be forgiven for this. You can guess the reaction: Chelyabinsk has no conservatory, meanwhile in Magnitogorsk, there will be one". That is why, he proposed to us to act self-dependently.

\section{MAKE HAY WHILE THE SUN SHINES}

Soon, the time came of re-election of Chelyabinsk's governor, positions of which were quite weak in those days: he failed to get the economic mechanism up and running, to ensure a stable economics development; constantly pensioners' allowances were delayed as well as salaries and wages of employees paid from state budget. It was clear that his activity in this position came to the end. An interesting politician, democrat-oppositionist - in his nature, he was similar to Yeltsin: he was a rebel, who permitted much but was not able to build up a management system in the region, perhaps, because of lack of a manager's talent.

It became known that in connection with his pre-election campaign, the governor would come to Magnitogorsk for a meeting conduct with metallurgists (1996). The municipal administration asked me entering to the organized especially for him support-group. In a hope of making use of the opportunity, I prepared a project of regional governor's decree and acquainted the municipal administration with it - the town's mayor and the director of the metallurgical complex A.I. Starikov. I said, "When governor would come for the meeting with electorate, I shall be close. We need to convince him already here, on-site, signing the order on renaming Musical-pedagogical institute to a conservatory". The complex's Director waived with his arm, "Don't worry, it'll be done".

For the meeting with the governor, more than thousand electors came. The first speaker was the General Director of the metallurgical complex, who - for decencies - spoke that Magnitogorsk has got a great friend - the governor. The audience started grumbling, stamping feet, someone whistled. The governor was discouraged. Coming to the microphone, he started telling, how much he was doing for region residents, for agricultural workers and for pensioners. The more he spoke, the worse the audience outraged. In a tactile sense, I believe, he acted in a wrong way. He should repent saying that a great deal of mistakes had been made but he

*In Russia, the social status of conservatory is much higher that a status of some universities. knew how to rectify them. The meeting came to end with a scandal: metallurgists did not permit him finishing his speech and asked the candidate to governor position going away from the stage.

It was known that after the meeting together with the complex's director, he would go to a television studio, where he would continue his election campaign. I went to the same address and - having waited for his telecasting speech end I came to the governor, stretched out the project of the order on transformation of the musical-pedagogical institute into a conservatory and asked him signing it. With the intrinsic-toclerks enthusiasm, the governor pledged his support though doubting loudly about an advisability of the renaming. Nevertheless then he asked for a delay in time for documents coordination in relevant region's agencies; then the director of the complex said insistently, "Why, what is here to discuss? Sign!"

Our plan was precise: for the three days left before the elections, governor would have no time to do something with our document. The director of the complex added, "Well, listen, you will support Magnitogorsk and in its turn Magnitogorsk - you". These words worked magically. The governor signed the order project. After giving out my bows, I took off literally like a shot from a gun of the studio.

It was 10:00 p.m., meanwhile at 10:50 p.m., the train departed to Chelyabinsk. It was necessary to send someone immediately to the regional center for registration of the order because there was signed only the order project and tomorrow was Friday. So, only one day had been left. I called to my pro-rector on science M.M. Berlyanchik: "Urgently, prepare yourself for the trip to Chelyabinsk and do not return unless you would register the order so it would become effective". In 10 minutes, I was at his home.

We came to the railway station - there was no single ticket! We approached to the train, "Where is the chief?" In a minute, he came to us and the following talk had place between us.

“Are you Magnitogorsk's resident?"

"Yes, Magnitogorsk's."

"We would like to establish a music conservatory in Magnitogorsk and today a little while ago, the governor put his visa on the relevant document. But until now, this is only a project. Tomorrow, he will be in authority his last day. See, this is our pro-rector on science. For one day, he must have time to register everything in Chelyabinsk. If he would not have enough time, so there will not be a conservatory in Magnitogorsk. He has to go but there are no tickets".

"Well, what if controllers will come suddenly?" The train chief asked.

"We shall rescue: the town's mayor and the director of the complex will prop you up. Do not be scared!"

"Ah, hang it all!, come on, climb upstairs", the train chief concluded. 
He helped to M.M. Berlyanchik entering to the already almost moved off train. As it got clear later on, he gave away to him his official place and thus the travel to Chelyabinsk was quite comfortable.

For everyone, who stayed in Magnitogorsk, the long hours of anxious waiting were dragging slowly. The entire next day, Mark Moiseyevich conducted the obtaining of the necessary approvals, and as late as about at five o'clock afternoon the leaving governor signed his last order. Finally at 5:00 p.m., Mark Moiseyevich called to me and informed in a quiet voice that the affair had been done, the document had been registered. Literally, I soared above my chair. We were happy as children. Soon, our prognoses found a confirmation: Another candidate was elected as governor and he suspended validity of orders that his predecessor signed within last two months. (Apparently, he had an anxiety that for the sake of the high position retention, the previous governor could declare promises, acting up to which would be above new administration's strength).

Finally, time came that it was turn of our order. It got for an expert evaluation to financial board of the region. We had to wait for making decision for quite a long time. What to do? $\mathrm{Be}$ in fuss, try and convince financial experts? But exactly this kind of activities could make harm; - the new mangers hardly knew us. The tactics of waiting turned to be the most correct as it was indifferent for the financiers, what functioned in Magnitogorsk and whether it was a mus-pedinstitute or a conservatory. They gave their conclusion that the status of conservatory would not result at any additional expenses from the region's budget. (See, what a correct formula can do!) So the new governor confirmed the validity of the order of the previous governor. In such way, this almost detective story came to the end.

Today, Magnitogorsk has its musical conservatory, which it cherish and take care of - The educational institution became a key factor in development of the infrastructure of the town's culture. With the conservatory establishment, the cultural sphere started changing qua qualitatively: Now, emphasis was made on the professional art instead of an amateurish creative works. Gratifying to the conservatory's work in the town, there were established Philharmonic Hall, Opera House and other professional creative teams. Also a cultural layer of town's residents started expanding. Hopes are present on a transformation of a socio-cultural cycle, which would allow increasing the cultural level of the town.

\section{POSTSCRIPT}

Among some Magnitogorsk's residents, there is a misunderstanding of the essence of the process of our reforms. Managers can get an impression that the music high school was re-organized into the conservatory. Reader, please, take my word for it: there was not a re-organization as a such. The music high school was preserved; it just passed into the status of the college. There was established a musical educational institution of a new type as in its structure, apart from higher link, it included also a middle and a primary links - a college and a special music school.
We took in the consideration that opening a conservatory as a new institution would be allowed by nobody. And that is why we invented the move, which made it possible to realize the intended plan of establishment of a single three-level educational structure. I propose to you to look at the transformations process from positions of an analysis of structural departments.

Schematically, it looked as follows: in the structure of the music high school, a special music school was open, personnel and subsidies on which were obtained in the course of the activities expansion. Then above the music high school, there was overbuilt a new grade, the higher educational institution. This was accomplished by the way of transferring management functions from the music high school to the higher link, while the music high school became its structural department. This way, the higher educational institution-complex appeared: the conservatory with its own special musical school and own college in its structure.

As a matter of fact, the method was invented of multiplication of potential legal bodies by the way of attribution to them of a status of new structural departments. The management functions transfer from one structural department to another one was needed, in order that the hierarchy of the management got fit to the existing system (school-music high school-higher educational institution). In its turn, legal bodies in the status of structural departments caused no objections in the course of approval obtaining of the institute by financial experts.

About tactics. If we would insist on an establishment of a new educational institution at the same time with preservation of old one in its structure, they would refuse and give us the fluff. That is why we used to affirm that the music high school was re-organized into a higher educational institution. This sounded quite harmlessly as from economical and legal points of view - it was referred to a certain improvement, which was patronized always and by everyone. Upon such formulation, the accent was put on a question: do we really deserve such status? The previous governor did not work out such delicate points. The new administration unriddled my tactics; nevertheless it was not inclined destroying the work done. Since the described events, many years passed. Now it is possible to summarize the reforms conducted somehow.

The contingent of the previously existed music high school made 400 students; now in the three established educational institutions, 860 people are studied together with postgraduate courses and doctorate. Nowadays at Magnitogorsk's conservatory, Council acts on defense of Ph.D. theses and doctorate theses on the specialty 170002 "Musical art". Everything done is a result of goal-oriented search directed on improvement of manpower training in Russia in the area of musical art and hence on musical culture development.

From the said in this chapter, young managers should make the following conclusion: the life opens up a great deal of opportunities - One should just find methods of solutions being adequate to a conception. Being quite young man and 
having no economical education, I brought those formulas into existence without any assistance from outside. Now I can be proud that our musical youth in Magnitogorsk has a chance to go into higher education not only in the capital or major cultural centers of Russia but also at their own home.

With time, the Magnitogorsk's conservatory earned the honor of having the status of Academy and today, its graduates work successfully in Russia and abroad demonstrating a high level of not only professional training but social alertness, too. Brought up on examples of positive reforms, they are able to attract a society's heightened attention to activities, which they are dedicated to.

The example and the experience of Magnitogorsk turned out to be contagious: today, after the manner of the Magnitogorsk's conservatory, in Russia, there function higher educational institutions-complexes in Tambov (Musical-pedagogical institute named after S.V. Rakhmaninov), Chelyabinsk (Institute of music named after P.I Chaikovsky), Moscow (Institute named after Hippolitov-Ivanov, Institute of music named after A.G. Shnitke), Volgograd, Ulyanovsk and other towns of Russia (institutes).

With time, the young higher educational institutions strengthened their financial positions, material resources and teaching staff. Both de jure and de facto, they crystallized into higher educational institutions of full value; meanwhile, to the full extent, the life and results of their activities confirmed the promising potential of this model of reforms.

Thus, Magnitogorsk's reforms grew up into the major All-Russian movement, which renders its positive action on development of cultural processes in the entire country.

\section{CONCLUSION}

\section{A. Some private considerations in traces of the said}

In conditions of a formed hierarchy and an absence of an institution entrusted to you in a state program of development, the best method of building your structure up will be use of so called principle of permeation (from small forms to bigger ones).

Apart from bureaucrats and clerks, a hierarchy was thought out by the least gifted people, clinging and tightening a stranglehold over their place and eager to climb upper on a career ladder. More often than others, they block initiatives of managers-enthusiasts.

It is necessary to learn how to put off guard of bureaucrats by a demonstration of your obedience and commitment to play strictly adhering to their rules. By your actions and words, it is necessary to convince authorities in force that you do not infringe upon their interests at all; more to it, all you propose has undoubted advantage for them.

Always, conflicts/scandals are prognosticators of a destruction of both a business and its participants. Planning reforms, one should avoid conflicts.
Hundred times, Nietzsche was right: "it is impossible to vault upon a horse, which was not saddled up by you". To an idea of somebody else, it is easy to join; but you can not realize it unless it sent down its roots into your brains, into your entire essence.

More often than not, the state can not solve this or that problem wherefore officials do not want (are afraid to take risk) or do not know ways of its solution. If a solution method is clear to a manager, there is no sense in his throwing up his cards, he should be braver and undertake his task.

\section{B. Measures list at reforms preparation in social sphere}

A manager needs to do as follows:

-gather support of his colleagues;

-arrange a necessary outreach campaign in mass-media (if this is a major project);

-gain support of even one member of a higher rank of administration (better yet one in each level of the entire hierarchic chain of management organs including the federal level);

-find even one sympathizing fellow among possible opponents;

-develop a reforms conception - this will allow you predicting problems that would become likely in the course of the plans realization;

-initiate a public discussion on the given topic; it will help to colleagues finding way around the entire array of issues accompanying your realization of the developed plan of actions.

\section{Some generalizations having been formed after project realization}

Reforms are impossible without actions; one should act every minute, in any environ and under any circumstances.

The more large-scale are reforms, the more major figures should be engaged in them. Working on the upper level of clerks' hierarchy, do not forget also about the lowest one because folk wisdom reads "If a small clerk would not want, Minister will not vault".

Always it is necessary to raise the bar of requirements to yourself. H.G. Neuhaus was right saying "In seeking for impossible, we reach possible".

It is necessary to study the tiniest details of on-coming business, to enter deeply into issues and first of all to learn how to present them in a structured fashion as a sum of smaller ones because details of reforms are easier comprehended.

\section{REFERENCES}

[1] Salmon, R. The Future of Management, Blackwell Business, 2004

[2] Cameron, Kim S., Quinn, Robert E. Diagnosing and Changing Organizational Culture, Addison-Wesley, 2001 
[3] Mintzberg, H., Ahlstrand, B., Lampel, J. Strategy Safari, Prentice Hall, 2001

[4] Mintzberg, H. Structure in Five, Prentice/Hall International, Inc., 2002

[5] Zub, A.T. Strategic Management. Theory and Practice. Aspect Press, M., 2002 